\title{
ZMAGANIA SŁOWACKO-WĘGIERSKIE W POSTRZEGANIU WSPÓLNEJ HISTORII
}

\author{
RYSZARD GRZESIK
}

\begin{abstract}
Ryszard Grzesik, Zmagania słowacko-węgierskie w postrzeganiu wspólnej historii (The SlovakHungarian Struggles in the Interpretation of the Common History).
\end{abstract}

Balcanica Posnaniensia. Acta et studia, XIX, Poznań 2012, Wydawnictwo Instytutu Historii UAM, pp. 31-37, ISBN 978-83-63-047-17-7, ISSN 0239-4278. Polish text with a summary in English.

Ryszard Grzesik, Zakład Historii Instytutu Slawistyki PAN, Poznań, Polska - Poland.

Wśród procesów społecznych i kulturowych składających się na tożsamość różnych grup ludności ważną rolę odgrywa świadomość historycznych związków z bliższymi i dalszymi sąsiadami. Należy ona do sfery faktów kulturowych, często zmitologizowanych, kreujących mapę wzajemnych sympatii i antypatii. Nie wzięły się one znikąd, lecz mają głębokie uzasadnienie $\mathrm{w}$ dziejach tych grup. Wyobrażenia i stereotypy, w jakie przekształca się pamięć o pojedynczych wydarzeniach, jak i o całokształcie dziejów, zakorzenione są w przeszłości.

W Europie Środkowej napotykamy dwa ciekawe mity dotyczące przeszłości, które związane są z Węgrami. „Bohaterem” jednego z nich jest Polska, drugiego Słowacja. Pierwszy jest w Polsce powszechnie znany. To mit o „wieczystej” przyjaźni polskowęgierskiej, zilustrowany dobrze znanym przysłowiem: „Polak-Węgier, dwa bratanki i do miecza i do szklanki"”. Drugi to o wiele mniej przyjazne stosunki słowacko-węgierskie. Analizując historię XX w. dostrzegamy nieraz obawy Słowaków, jako narodu „młodszego” i mniejszego przed ich południowym sąsiadem. Strach przed rzekomą irredentą węgierską dyktował politykom niepodległej już Słowacji ustalenie

${ }^{1}$ Temu zagadnieniu poświęcona była dysertacja doktorska A. Quéret-Podesty: A. Quéret-Podesta, „Polonais, Hongrois, deux frères" (Polak, Węgier, dwa bratanki..., Magyar, lengyel, két jó barát). La représentation des plus anciennes relations polono-hongroises dans l'historiographie du Moyen Âge à nos jours et la question des origines médiévales du mythe de l'amitié polono-hongroise. Thèse de doctorat en Histoire du Moyen Âge préparée en cotutelle internationale, [Clermont-Ferrand 2010], niepublikowany wydruk komputerowy. 
dzisiejszego podziału administracyjnego kraju, który nie ma nic wspólnego z podziałami historycznymi, a niekiedy wręcz rozbija historyczne terytoria (jak np. Spiszu). Omawiany proces sięga swoimi korzeniami przynajmniej XIX w., pojawił się on $\mathrm{w}$ dobie powstawania nowoczesnych świadomości narodowych².

Lecz początków słowackiej świadomości etnicznej i antagonizmów dzielących dzisiejszych Słowaków i Węgrów możemy szukać już w średniowiecznym kronikarstwie węgierskim. Jak wiadomo, wczesnośredniowieczne kroniki ukazywały między innymi chwalebną przeszłość „grupy trzymającej władzę”. Tworzyli ją dynasta z rodziną oraz najbliższym otoczeniem - drużyną i urzędnikami. Wszyscy oni tworzyli instytucję państwa, a kroniki dostarczały wspólnej wizji przeszłości i ram ideowych, uzasadniających istnienie tego państwa ${ }^{3}$. W przypadku Węgrów kronikarze odpowiadali na pytanie, jak przybysze z dalekiej Scytii dotarli do Panonii, kogo tam napotkali, w jaki sposób pokonali i podporządkowali sobie tubylców oraz jak zbudowali swoje państwo. Była to wizja podboju dzisiejszych Węgier. Na niej skoncentrował się np. anonimowy kronikarz, zwany często magistrem P., notariusz króla Béli, najpewniej III, piszący na samym początku XIII w. Jednym z przeciwników Węgrów był wódz bułgarski Salan, władający międzyrzeczem Cisy i Bodrogu. Podczas spotkania z jego posłami węgierski wódz Arpad poprosił go o tereny pod wypas bydła na wschód od rzeki Sajó, dwa dzbanki dunajskiej wody oraz wiązkę siana z puszty Alpár, w zamian ofiarując księciu bogate dary. Książę z radością je przyjął nieświadom, że właśnie pozbywa się swojego władztwa. Węgrzy szybko mu to uświadomili, domagając się opuszczenia ziemi przez Salana i egzekwując to zbrojnie. Chciałoby się westchnąć, że to jedno $\mathrm{z}$ wielu dyplomatycznych nieporozumień, które zmieniają dzieje świata ${ }^{4}$.

Bardzo podobnie przedstawia to wydarzenie grupa kronik z XIV w., wydanych swego czasu przez Sándora Domanovszky'ego. Dowiadujemy się z niej, że Arpad wysłał poselstwo do lokalnego władcy, prosząc go o dar ziemi, siana i wody ofiarując w zamian konia arabskiego cudnej urody z pozłacaną uzdą i siodłem. Miejscowy książę dar przyjął, ale potem z zaskoczeniem dowiedział się o żądaniu ustąpienia przybyszom swego kraju. Nie będzie dla nas zaskoczeniem, że Węgrzy wyegzekwowa-

${ }^{2}$ Ze starszej literatury o kształtowaniu się odrębności słowackiej zob. napisany z wielką sympatią wobec Słowaków artykuł Lajosa Gogoláka z 1942 r., L. Gogolák, A szlovák és ruszin nemzetiség története, w: A magyarság és a szlávok, red. Gy. Szekfü, wyd. 2, wyd. E. Niederhauser, Budapest 2000, s. 205-218. Rozwój historiografii słowackiej opisują np. F. Kutnar, J. Marek, Přehledné dějiny českého a slovenského dějepisectví od počátkủ národní kultury až do sklonku třicátých let 20. století, Praha 1997; E. Niederhauser, A történetírás története Kelet-Európában, Budapest 1995, s. 568-613. Godną polecenia pracą na temat konfliktów narodowościowych w XIX-wiecznym Imperium Habsburgów jest H. Wereszycki, Pod berłem Habsburgów. Zagadnienia narodowościowe, Kraków 1986. Świadectwem z epoki jest powieść Artura Gruszeckiego, ukazująca zmagania Słowaków z postępującą madziaryzacją: A. Gruszecki, W tysiąc lat. Powieść na tle stosunków stowacko-węgierskich, Warszawa 1902.

${ }^{3}$ B. Kürbisówna, Więź najstarszego dziejopisarstwa polskiego z państwem, w: Poczatki państwa polskiego. Ksiega Tysiqclecia, red. K. Tymieniecki, G. Labuda, H. Łowmiański, Poznań 1962, t. 2, s. $217-$ -218 .

4 Anonimowego notariusza króla Béli Gesta Hungarorum, wyd. A. Kulbicka i in., Kraków 2006, rozdz. 14, s. 74-79, rozdz. 16, s. 82-85 (tekst równoległy łaciński i polski przekład). 
li swe prawa przymusem, zaś dotychczasowy władca, uciekając przed nimi, utonął w Dunaju ${ }^{5}$.

Zaciekawi nas zapewne, że tym władca, negatywnym bohaterem tzw. podania o białym koniu, jednego z podstawowych podań legitymizujących władzę węgierską, był Świętopełk. Nie była to postać obca kronikarzom węgierskim, bo pojawia się on już u Szymona z Kézy, piszącego w latach 1282-1285 na dworze Władysława IV Kumańskiego. Świętopełk był, jego zdaniem, synem Marota, księciem polskim, który podbił Braktę i władał Bułgarami i Messianami, a po wygnaniu Hunów rządził i w Panonii. Miał w niej rządzić Marot, ale ponieważ był już stary i słaby, osiadł w grodzie Veszprém. Świętopełk przeciwstawił się Węgrom, którzy sforsowali Dunaj w Peszcie i Szobie i pokonali go. Ale według innej tradycji pobili go nad rzeką Rákos koło Bánhidy. Ponoć jego ojciec, gdy o tym usłyszał, wyzionął ducha ${ }^{6}$.

Czy Świętopełka spotkał aż tak tragiczny koniec, jak przedstawiają kronikarze węgierscy? Niekoniecznie. Bo gdy otworzymy Kronikę Czechów napisaną w trzeciej dekadzie XII w. przez praskiego kanonika Kosmasa, ze zdziwieniem przeczytamy o Świętopełku, który ponoć zniknął spośród swego wojska i nigdy się już nie pojawił. Lecz twierdzi się też, że Świętopełk, nękany wyrzutami sumienia za bunt przeciwko swojemu panu, królowi Arnulfowi, w nocy zabił konia, połamał miecz i w szacie pokutnej udał się do pustelników żyjących na zboczach góry Zobor, górującej nad Nitrą. Tu przez lata przebywał nierozpoznany, a kim jest, ujawnił dopiero na łożu śmierci ${ }^{7}$.

O tym, że był to potężny władca, przekonuje lektura najstarszej kroniki południowosłowiańskiej, znanej jako Latopis popa Duklanina. Za czasów tego króla doszło do zjazdu na równinie Dalma, na którym faktycznie ustanowiono system administracji politycznej i kościelnej państwa Svevladiciów ${ }^{8}$. Działalność ta bardzo przypomina skrótowo przedstawione dokonania Akwili - Attyli, potężnego władcy Węgrów, który w opinii kronikarza węgiersko-polskiego, działającego pod koniec lat 20. XIII w. na sławońskim dworze Kolomana halickiego, był właściwym twórcą węgierskiej państwowości w ziemi słowiańskiej, rozciagającej się między Dunajem a Cisą. Władca ten i jego poddani poślubili tubylcze kobiety, w ten sposób nabywając prawo do nowych siedzib ${ }^{9}$. Co ciekawe, małżeństwo węgierskiego następcy tronu z córką księ-

${ }^{5}$ Chronici Hungarici compositio saeculi XIV, wyd. A. Domanovszky, w: Scriptores rerum Hungaricarum, t. 1, Budapest 1937, rozdz. 28, s. 287-290.

${ }^{6}$ Najnowsze wydanie: Simonis de Kéza Gesta Hungarorum. Simon of Kéza, The Deeds of the Hungarians, wyd. L. Veszprémy, F. Schaer, with a study by J. Szücs, Budapest - New York 1999, rozdz. 23, s. 72-77 (z tłumaczeniem angielskim).

7 Die Chronik der Böhmen des Cosmas von Prag, wyd. B. Bretholz, Berlin 1923, wyd. 2, München 1980, I 14, s. 32-34. Polski przekład: Kosmasa Kronika Czechów, tłum. M. Wojciechowska, Warszawa 1968, s. 124-126.

${ }^{8}$ Ljetopis popa Dukljanina. Latinski tekst sa hrvatskim prijevodom i „Hrvatska kronika”, [wyd. V. Mošin], Zagreb 1950, rozdz. 9, s. 48-57. Polski przekład: Historia Królestwa Stowian czyli Latopis Popa Duklanina, wyd. J. Leśny, Warszawa 1988, s. 67-73.

${ }^{9}$ Chronica Hungaro-Polonica. Pars 1 (textus cum varietate lectionum), wyd. B. Karácsonyi, Szeged 1969 (Acta Historica, t. 26), rozdz. 3, s. 19-20. Polski przekład: Żywot św. Stefana króla Węgier czyli Kronika węgiersko-polska, wyd. R. Grzesik, Warszawa 2003, s. 61-62. 
cia biharskiego Menumoruta u znanego nam już Anonima stanowiło jeden z aspektów legitymizacji węgierskiego panowania. A słowo Marót wchodzące w skład imienia tego księcia to węgierskie określenie Morawianina, sama zaś postać to alegoria Świętopełka ${ }^{10}$.

Jak widzimy z tego pobieżnego przeglądu źródeł, na rozległych obszarach Europy Środkowej utrzymywała się przez wieki średnie tradycja o państwie wielkomorawskim oraz o jego władcy, Świętopełku. W innym miejscu starałem się już wykazać, że pamięć o pierwszym trwalszym państwie Słowian Zachodnich przetrwała $\mathrm{w}$ dwóch aspektach ${ }^{11}$. Pierwszym z nich był aspekt kulturowy, to jest kultywowanie jego dziedzictwa literacko-religijnego, wypracowanego przez misję św. Cyryla i Metodego i zachowanego w największej skali przez słowiańską kulturę prawosławną. Oczywiście pamiętamy tutaj i o roli katolickich chorwackich głagolaszy. Drugim aspektem tradycji wielkomorawskiej był aspekt polityczny, a zatem pamięć o królu Świętopełku, istotnie najpotężniejszym władcy morawskim. Jak pokazuje zespół podań, odnotowanych przez kronikarzy i często się wykluczających, funkcjonowała ona w tradycji ustnej, przypisanej do różnych obszarów geograficznych i wykorzystanej przez dziejopisów do własnych celów politycznych ${ }^{12}$.

Ostatnio postacią Świętopełka zainteresowali się dwaj badacze słowaccy: Martin Homza i jego uczennica, Nad’a Rácová ${ }^{13}$. Martin Homza zanalizował m.in. występowanie tego władcy w kronikarstwie średniowiecznym wyróżniając w nim białą i czarną legendę Świętopełka. Na białą legendę składa się wzmianka Kosmasa o jego pobycie w zoborskiej pustelni, dzięki któremu osiągnął on wymiar świętości. Czarny obraz malują kronikarze węgierscy w omówionym już podaniu o białym koniu. Stał się on częścią węgierskiej ideologii państwowej, co ostatecznie przypieczętował Jan Thuróczy, przekazujący myśl średniowiecza dalszej epoce. Ideologia ta opierała się na przeświadczeniu, że węgierska szlachta mieczem i podstępem zdobyła sobie władzę w Królestwie, ma zatem pełne prawo do rządów, m.in. nad ludem Świętopełka, z zasady jej poddanym ${ }^{14}$.

Lecz XVI w. przyniósł Węgrom tragiczną klęskę doznaną z rąk Turków pod Mohaczem. W jej wyniku doszło do wojny domowej między zwalczającymi się stronnictwami oraz do zajęcia znacznych połaci kraju przez Osmanów. Północna i zachodnia część kraju znalazła się pod władzą Habsburgów. Zamieszkała ona była w prze-

10 Por. np. R. Grzesik, Menumorout i inni. Wielkie Morawy w węgierskich kronikach średniowiecznych, w: Czas, pamięć, tradycja. Materiały konferencji, red. Bożenna Bojar, Warszawa 2010, s. 87-94.

11 R. Grzesik, Great Moravia as a Basis of the Central European Medieval Historical Tradition, złożone do druku w materiałach sesji: Slovensko a Chorvátsko. Historické paralely a vzt'ahy (do roku 1780), która miała miejsce w Bratysławie i Lewoczy 20-24 czerwca 2011.

12 Np. J. Steinhübel, Nitrianske kniežatstvo. Počiatky stredovekého Slovenska. Rozprávanie o dejinách nášho územia a okolitých krajín od st'ahovania národov do začiatku 12. storočia, Bratislava 2004, s. 165-186.

13 M. Homza, N. Rácová, K vývinu slovenskej myšlienky do polovice 18. storočia. Kapitoly k základom slovenskej historiografie. Učebné texty, Bratislava 2010.

14 M. Homza, Počiatky Svätoplukovskej tradicie u Slovákov. Čierna a biela Svätoplukovská legenda, w: tamże, s. 39-74. 
ważającej mierze przez ludność niewęgierską: saskich osadników przeważających w miastach i słowiański lud. Ten ostatni zaczynał być coraz bardziej widoczny ${ }^{15}$. Reformacja i kontrreformacja wymusiły na obu stronach konfliktu religijnego potrzebę docierania ze swymi argumentami do szerokiego ludu. Zaczęły powstawać teksty w języku czeskim, zrozumiałym dla miejscowych i dobrze już ugruntowanym, jako język literacki. Zawierały one jednak wzrastającą z biegiem lat liczbę słowakizmów. Zresztą i administracja miejska od drugiej połowy XV w. w coraz większym stopniu dopuszczała zesłowakizowaną wersję czeskiego. I katolicy, i protestanci poszukiwali wspólnego dla wszystkich Słowian języka. Zwróciły one wtedy uwagę na dzieło katolickich głagolaszy. Przez lata obowiązywał pogląd, że twórcą języka starocerkiewnosłowiańskiego (choć tej nazwy jeszcze nie znano) oraz alfabetu głagolickiego był sam św. Hieronim, twórca łacińskiego przekładu Biblii, czyli Wulgaty, największy autorytet biblijny, jakiego można było sobie wyobrazić. W ten sposób dowodzono prawowierności samego języka oraz pisma i broniono się skutecznie przed zarzutem herezji. Ale już autor pierwszego katolickiego śpiewnika po słowacku, Benedek Szőllősi dowodził, że jest ono rezultatem misji Cyryla i Metodego, Apostołów Słowian, przyjętych przez Świętopełka. Władca ten rezydował w Székesfehérvárze, późniejszym mieście koronacyjnym królów węgierskich, jego państwo stało się zatem podwaliną państwowości węgierskiej. Autor ten, jako pierwszy połączył zatem rozdzielone dotąd oba nurty tradycji o Wielkich Morawach, wprowadził też na stałe postać Świętopełka na karty węgierskiej historiografii krytycznej ${ }^{16}$. Zainteresowanie wielkomorawska przeszłością, zdaniem Nadii Rácovej, było typowe dla nurtu katolickiego ${ }^{17}$. Jego reprezentantem był Marcin Szentiványi, który wyróżnił trzech Świętopełków: I, który oddał ziemię Węgrom, II, który zmarł w opinii świętości na Zoborze oraz III, jego syna, za którego panowania upadły Wielkie Morawy ${ }^{18}$.

Do prawdziwej awantury doszło w 1722 r., kiedy wyszło dzieło profesora Uniwersytetu w Trnawie, Michała Bencsika, w którym dowodził, że heretycy nie są równoprawnymi obywatelami Królestwa Węgierskiego, m.in. dlatego, że są potomkami ludu Świętopełka, podbitego przez Węgrów i zmienionego na wieki w ludność poddańczą. Odpowiedź napisał kilka lat później, w 1728 r., proboszcz z Dubnicy nad Wagiem, Jan Baltazar Magin, który z kolei dowodził, że Świętopełk dobrowolnie przyjął do swojej krainy węgierskich przybyszów i pozwolił im żyć wśród swego ludu. To pokazuje jego wielkoduszność i szlachetność. Dlatego wszystkie narody tworzące Królestwo Węgierskie są równe ${ }^{19}$.

15 W dalszym ciągu opieram się na rozważaniach N. Rácovej: N. Rácová, K vývinu slovenskej myšlienky v 17. storočí, tamże, s. 121-187 oraz tejże, K d’alšiemu vývoju slovenskej myšlienky do polovice 18. storočia, tamże, s. 189-246.

16 M. Homza, N. Rácová, K vývinu, s. 18 (część M. Homzy), 146-150 (część N. Rácovej; w przyp. 66 podany pełen tytuł kancjonału).

17 Tamże, s. 185-187. Ewangelicy tymczasem zwracali większą uwagę na rolę własnego języka w liturgii, ale też uważali braci sołuńskich za swoich przodków.

18 Tamże, s. 173-185.

${ }^{19}$ Analiza tamże, s. 195-213. 
Dwa wspomniane dzieła, Bencsika i Magina, otwierają dwa nurty węgierskiej historiografii krytycznej, widoczne wyraźnie od początku XVIII w. Nie mają one polskiej nazwy. Jeden $\mathrm{z}$ nich nazywany w historiografii słowackiej podmanitelskou teóriou głosi, że etniczni Węgrzy powinni zajmować dominujące stanowisko w wieloetnicznym Królestwie Węgierskim. Jego reprezentantami w późniejszych latach byli uczeni jezuici, zasłużeni dla pierwszych węgierskich edycji źródłowych, György Pray i István Katona ${ }^{20}$. Nurt ten stał się nie tylko oficjalnym nurtem historiografii węgierskiej, ale i uzasadniał prowadzoną w XIX w. politykę madziaryzacji niewęgierskich mieszkańców Korony św. Stefana ${ }^{21}$. Doprowadziła ona, jak wiemy, do rozpadu Węgier i tragicznego dla Węgrów traktatu trianońskiego, do dziś stanowiącego jedną z głównych traum przeciętnego Węgra. Drugi nurt, zwany pohostinskou teóriou, przez długie lata podkreślał równoprawność narodów Węgier i artykułował przywiązanie do wspólnej, węgierskiej ojczyzny, podkreślając zarazem rolę czynnika słowiańskiego w jej dziejach. Mieścił się w nim Samuel Timon, Juraj Papánek, nawet jeszcze działający na przełomie XIX i XX w. ks. František Vit’azoslav Sasinek. Stopniowo jednak wyodrębniał się w samodzielną historiografię słowacką̨ ${ }^{22}$.

Rezultatem tego rozwoju było powstanie dwóch historiografii narodowych. Bardziej rozwinięta wydaje się być węgierska, badająca dzieje dawnych Wegier w ujęciu całościowym. Historycy węgierscy nie boją się analizować historii komitatów wchodzących w skład dzisiejszej Słowacji, rumuńskiego Siedmiogrodu czy serbskiej Wojwodiny albo innych ziem pozostających poza granicami współczesnych Węgier. Historycy słowaccy z kolei koncentrują się przeważnie na tematyce wielkomorawskiej, mniej zajmującej ich węgierskich kolegów, zaś badając dzieje Słowacji w ramach Korony Węgierskiej rozpatrują historię wyłącznie terenów dzisiejszej Słowacji, nie interesując się już innymi ziemiami węgierskimi. Z punktu widzenia ogólnowęgierskiego są to badania regionalne, cenne dla poznania dziejów lokalnych, ale niekiedy tracące $\mathrm{z}$ oczu szersze procesy zachodzące na całości ziem Królestwa Węgierskiego ${ }^{23}$. Na szczęście ta sytuacja ulega zmianie. Istnieje na przykład świadomość podobieństwa rozwoju Spiszu i Siedmiogrodu. Latem 2011 r. w Bratysławie odbyła się sesja naukowa poświęcona kontaktom Słowacji z Chorwacją do XVIII w. z udziałem silnej reprezentacji węgierskiej ${ }^{24}$. Optymizm budzi mocno podkreślana świadomość uczestników, że przedmiotem obrad stały się więzi istniejące w ramach wspólnego państwa - Korony św. Stefana. Można zatem patrzeć w przyszłość

20 S. B. Vardy, Modern Hungarian Historiography, New York - Guildford, Surrey 1976, s. 30-31 zalicza ich do jezuickiej szkoły edytorskiej (The Jesuit Source Collecting School).

${ }^{21}$ Dobrze scharakteryzowaną przez H. Wereszyckiego, Pod bertem Habsburgów, passim.

22 Por. prace cyt. w przyp. 2.

${ }^{23}$ Por. mój głos w ankiecie bratysławskiego czasopisma „Proglas”: Anketa o predmete slovenských dejín, „Proglas”, R. 10, 2000, nr 3-4, s. 20-22. Na konieczność znajomości przez badaczy słowackich dorobku historiografii węgierskiej i vice versa zwracał ostatnio uwagę L. Koszta, 11. századi bencés monostor a Szepességben?, „Századok”, R. 142, 2008, z. 2, s. 356; wersja słowacka tegoż, L. Koszta, Benediktínsky kláštor z 11. storočia na Spiši?, prel. Vincent Múcska, Historický časopis, R. 57, 2009, z. 2, s. 356.

${ }^{24}$ Por. wyżej przyp. 11. 
z umiarkowaną nadzieją, iż badania historyków stopniowo przedostaną się do szerszego kręgu odbiorców, wpływając na większe porozumienie między tak bliskimi sobie Węgrami i Słowakami. Wtedy wspomniana na początku obustronna niechęć stanie się już jedynie tematem rozpraw historycznych.

\title{
THE SLOVAK-HUNGARIAN STRUGGLES IN THE INTERPRETATION OF THE COMMON HISTORY
}

\begin{abstract}
Summary
The consciousness of historical relationship with the neighbours belongs to important cultural facts, which create the map of common sympathies and antipathies. They are rooted in the past of nations or other social groups. Two interesting historical myths are connected with Hungary. One of them tells about the 'eternal' Polish-Hungarian friendship, the second one tells about the enmity of the Hungarians and the Slovaks. The aim of the article is to search the roots of this complicated Slovak-Hungarian relationship, which lie deeper than in the $19^{\text {th }}$ century. I analyzed the image of the Pannonian Slavs in the Hungarian chronicles. They played the role of people, who were conquered by the Hungarians or sold them their territories (Story of a white horse presented by the Anonymous Notary of King Béla and by the Chronicle composition of the $14^{\text {th }}$ century). Svatopluk, the Polish (in fact, the Great-Moravian) ruler, was one of the negative heroes of Simon of Kéza's Chronicle. I analyzed the information about this ruler in the Bohemian and South-Slavic (the Chronicle of Duklja) tradition, underlining the functional identity of Svatopluk of the Duklja Chronicle with Aquila/Atyla of the Hungarian-Polish Chronicle. It was an element of the tradition about the Great-Moravian statehood, preserving in Central-European oral and written tradition. Two aspects of this tradition could be seen in the sources: 1) the cultural one, concentrating on the activity of St. Cyril and Methodius and 2) the political one, i.e. the story of Svatopluk. This tradition was recently searched by the Slovak scholars, Martin Homza and Nad'a Rácová. I characterize the development of the reflection on Great-Moravia and the Slavic liturgy in historical Hungary (especially in contemporary Slovakia) basing on their study. Different interpretations of the role of the Slavs in the Hungarian state resulted in the creation of two national historiographies at the end of the $18^{\text {th }}$ century, the Hungarian and the Slovak. I tried to compare them. It is to observe that recently the historians from both countries, Slovakia and Hungary started to discuss on the facts from their common history. It creates the optimistic perspectives for the future.
\end{abstract}


